\title{
Kernos
}

Revue internationale et pluridisciplinaire de religion grecque antique

9 | 1996

Varia

\section{Orgeones in Phratries : A Mechanism of Social Integration in Attica}

\section{Yulia Ustinova}

\section{OpenEdition \\ Journals}

\section{Édition électronique}

URL : http://journals.openedition.org/kernos/1171

DOI : 10.4000/kernos. 1171

ISSN : 2034-7871

\section{Éditeur}

Centre international d'étude de la religion grecque antique

\section{Édition imprimée}

Date de publication : 1 janvier 1996

ISSN : 0776-3824

\section{Référence électronique}

Yulia Ustinova, "Orgeones in Phratries : A Mechanism of Social Integration in Attica », Kernos [En ligne], 9 | 1996, mis en ligne le 21 avril 2011, consulté le 21 avril 2019. URL : http:// journals.openedition.org/kernos/1171; DOI : 10.4000/kernos.1171 


\section{Orgeones in phratries:}

\section{A mechanism of social integration in Attica}

\section{Introduction ${ }^{1}$}

The word orgeon appears in the ancient Greek literature frequently enough to have been noted by the lexicographers, and rarely enough to require explanation. However, the picture delineated by the lexicographers' definitions differs significantly from that which is suggested by the epigraphic material produced in the Hellenistic and Roman periods by associations which were also called orgeones. These worshipped mainly foreign deities, could include xenoi and appeared later; they are not mentioned by the lexicographers ${ }^{2}$.

Nor are any distinctions drawn in the modern works of P. Foucart, F. Poland and E. Ziebarth ${ }^{3}$. W.S. Ferguson was the first to distinguish between different types of orgeones corporations and analyze the particularities of their organization and cult ${ }^{4}$.

But one crucial problem remained unsolved -that of the origins of the associations of orgeones. This article will attempt to demonstrate that the emergence of these institutions is connected with the history of the civic community in Attica and sheds some light on its early stages ${ }^{5}$.

1 I would like to thank Ari Paltiel who read this manuscript in draft and offered valuable criticisms and suggestions, and Prof. Wolfgang Zeev Rubinsohn for his support and advise.

2 The word orgeon could mean not only "a member of cult association", but also "a priest". To two examples, cited by PHOTIUS (s.v. ópye⿳亠丷厂६ৎ), W.S. FERGUSON (The Attic Orgeones, in HTbR, 37, 2 [1944], p. 131-132) adds two more: from Homer's hymn to Apollo (389) and from HERMESIANAX, Leontion, 19. However, there is no documentary evidence of a priestly office called orgeon.

3 P. FOUCART, Des associations religieuses chez les Grecs, Paris, 1873; F. POLAND, Geschichte des griecbiscben Vereinswesens, Leipzig, 1909; E. ZIEBARTH, Das griechiscbe Vereinswesen, Leipzig, 1896. - The subject is treated in detail in the Ph.D. dissertation: Yu. B. UsTINOVA, Private Cult Associations in Greece and on the Nortbern Black Sea Littoral (VI-I centuries BC), Leningrad, 1987, p. 20-21, 27-88 (in Russian).

4 Art. cit. (n. 2); Orgeonica, in Hesperia Suppl. 8 (1949), p. 144-162.

5 The limitations of space do not enable me to treat here the history of the thiasol that have apparently imitated the organization of orgeones. See USTINOVA, $o p$. cit (n. 3), p. 52-87, 144-162, and Private Cult Associations in Attica, in G.S. KNABE (ed.), Everyday Life and bistory in Antiquity, Moscow, 1988, p. 207-209 (in Russian). 


\section{The etymology of the word "orgeon"}

The corporations of orgeones were an exclusively Attic institution. Only in two instances does the word orgeones appear outside Attica: in Boiotia (Megara $I G$, VIII, 33, first century ${ }^{6}$ ), and in Teos (Michel, 1367, about the middle of the second century $)^{7}$. In both cases it seems to have been borrowed from Athens at a time when in Attica itself the different terms used for designating these corporations had already been merged.

The etymology of the word orgeon is obscure ${ }^{8}$.

The word orgeon has no derivative for designating a group or association, therefore during the classical epoch the orgeones called themselves simply

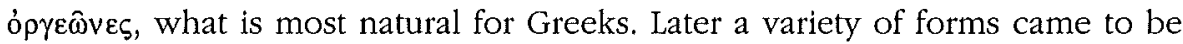

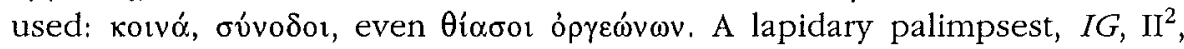
1246 , presents a curious example of such usage. Two decrees are incised on a cult table; in the first, from the fourth century, the corporation is called kovvóv,

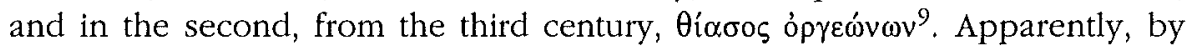
that time the distinction between orgeones, tbiasotai, and eranistai had become vague, and in the first century it disappeared entirely ${ }^{10}$.

\section{The organization of orgeones in the classical period}

In order to understand the origins of this institution, we need to obtain a clear idea of the results of its development. We shall do so by analyzing both lexicographic and epigraphic material dealing with the orgeones.

A number of lexicographic commentaries -those confusing orgeones with gennetai (Pollux, III, 52; Anecd. gr., I, 227; s.v. $\gamma \varepsilon v v \eta \hat{\tau}(\alpha)$ ), or orgeones with

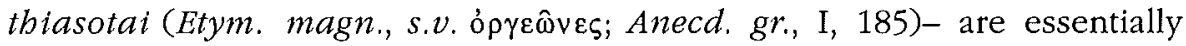
erroneous, but the reasons for this confusion are worth investigating. Other commentaries either accentuate the specific character of the associations of orgeones or the difference between them and similar corporations. These will be examined first.

Orgeones had already existed before Solon, since they were mentioned in his laws.

6 All the dates in the paper are $\mathrm{BC}$, unless otherwise indicated.

7 On the orgeones of Heracles on Lemnos see below, p. 232.

8 P. CHANTRAINE, Dictionnaire étymologique de la langue grecque, Vol. 1-5, Paris, $1968-$ 1980, s.v. ő $p \gamma 1 \alpha$; H. FRISK, Griechische etymologiscbes Wörterbuch, Band 1-3, Heidelberg, 1959$1972, s . v$. ö $\rho \nmid \alpha$. -Two other forms should be mentioned: ó $\rho \gamma \varepsilon \hat{\omega} \alpha_{\imath}$ in $I G, \mathrm{II}^{2}, 1280 \mathrm{a}$ (IIId cent. AD)

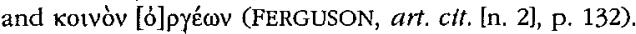

9 The last inscription published by S. Dow, D.H. GILL, The Greek Cult Table, in AJA, 69 (1965), p. 103-114

10 FERGUSON, art. cit. (n. 2), p. 143; cf. POLAND, op. cit. (n. 3), p. 13; ZIEBARTH, op. cit. (n. 3), p. $136-138$. 
Suda, Photius, s. $v$. ópyêิves:

Seleukos says in the memoirs on Solon's axones that orgeones are those

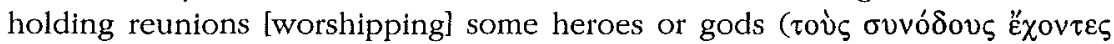

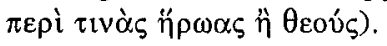

This testimony can be considered reliable since the author of a treatise on Solon's constitution must have known which laws belonged to the code of 594, and which though attributed to Solon, appeared later (Dem., 24, 142, esp. Andoc., 1, 82-83).

In the text the word "heroes" precedes "gods". This position is unusual and indicates, that Seleukos was aware of the orgeones' preference for the cult of heroes.

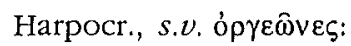

Orgeones are those who assemble to worship gods or heroes. To perform rites

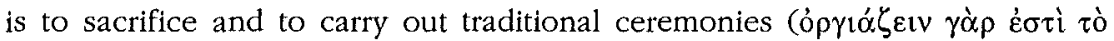

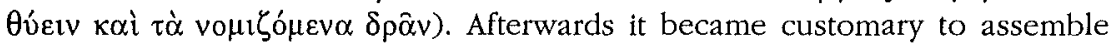
for the reverence of some deceased person and also be called orgeones.

Pollux, VIII, 107:

Orgeones are those who sacrifice on fixed dates in the demes.

Anecd.gr., I, 240:

...The state provides the cost of the public sacrifices, the demotai, that of the sacrifices of the demes, the orgeones, belonging to each shrine, that of their

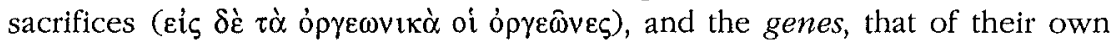
sacrifices.

These references make it possible to form an idea of the distinctive traits of the orgeones associations. They appear to have been groups of worshippers of certain heroes or gods who were scattered throughout Attica. On specific dates they assembled for participation in some cultic ceremonies at their own expense.

The tomb of the hero used to be the center of his cult, and the entire neighborhood was considered to be under his patronage; the nearer one was to the tomb, the more the power of the hero was felt. This is why the shrines of the orgeones were located in different parts of Attica: the orgeones who lived near the center of a particular hero's cult, would prefer to worship him. They would erect a shrine for him or, perhaps, use an existing one.

As stated above, these corporations differ considerably from the groups of orgeones known only from later inscriptions; the analysis of the particular traits of the latter is beyond the purposes of the present paper ${ }^{11}$.

11 On these associations see; FERGUSON, art. cit. (n. 2 and 4); USTINOVA, op. cit. (n. 3), p. 60-73. 
The most important source of information concerning the orgeones is to be found in their own documents. The article by W.S. Ferguson mentioned above contains a brilliant analysis of these inscriptions. The epigraphic evidence demonstrates, that the data of the lexicographers reflect the conditions in the classical period (the fifth-fourth centuries). By the later period (the third-first centuries), which is known from inscriptions only, these associations had changed substantially. As to the "classical type" of orgeones, it was most widely spread during the classical period, but continued to exist afterwards, though it was no longer dominant.

We may now consider the characteristics of the "classical model" of the orgeones' organization.

The inscriptions do not provide much information concerning the cultic practice of orgeones. Indeed, the orgeones usually worshipped heroes ${ }^{12}$. Sometimes the name of the hero was specified ${ }^{13}$, but sometimes he was called simply "the Hero" (as in the most ancient epigraphic document dealing with orgeones, dating back to the fifth century $\left.{ }^{14}\right)$. Hypodektes $\left(I G, \mathrm{II}^{2}, 2501\right)$ was also titled "the God", but this was obviously nothing more than a gesture of reverence towards a deity who was in fact a hero.

As laid down in their statutes, the orgeones assembled once a year to offer a joint sacrifice. From the contract between the orgeones of Egretes and a private person who rented a precinct and buildings which belonged to the orgeones $\left(I G, \mathrm{II}^{2}, 2499\right)^{15}$, we learn that the complex comprised a kitchen and a chamber, where the tables and the dining couches were located. Undoubtedly, the meat of the animals was not only divided, but roasted and consumed on the spot, with entire families enjoying the feast ${ }^{16}$.

This practice demands an explanation, for heroes were normally conceived chthonic deities, hence the flesh of the victims offered to them should not have been consumed, and the whole ritual should have been quite

12 On the heroes of orgeones see also: E. KEARNS, The Heroes of Attica, London, 1989, p. 7377.

13 Ekhelos (B.D. MERITT, Inscriptions from Areopagus, in Hesperia, 11 [1944], p. 284); Amynos, Asklepios and Dexion $\left(I G, \mathrm{II}^{2}, 1252,1259,1253\right)$; Egretes $\left(I G, \mathrm{II}^{2}, 2499\right)$; Hypodektes $\left(I G, \mathrm{II}^{2}, 2501\right)$.

14 MERITT, art. cit. (n. 13), p. 284.

15 The fact that the shrines were leased should be interpreted as evidence of enterprise, and not as an indication of the financial difficulties of the orgeones (FERGUSON, art, cit. [n. 2], p. 81, note 27). Indeed, the explanation is that the Athenian corporations, whether state (phratry, deme, genos) or private, did not maintain their property themselves, but received income only as rent from the private persons, holding the leases (M.I. FINLEY, Studies in Land and Credit in Ancient Athens, New Brunswick, 1951, p. 93 sq.) This practice is an additional testimony to the underdevelopment of the notion of the corporate person and corporate property in the Greek world (M. RADIN, The Legislation of the Greeks and Romans on Corporations, New York, 1911, p. 138-139; W. KAMPS, Les origines de la fondation cultuelle dans la Grèce ancienne, in Arcbives d'Histolre du droit oriental, 1 [1937] p. 145-179). 
different ${ }^{17}$. It would seem that many aspects of the cultic practice of the orgeones were inconsistent with the chthonic character which is usually ascribed to hero cults ${ }^{18}$. However, on the one hand, the distinction between the Olympic and chthonic rituals has never been absolute, and the borders between them were disregarded or blurred not infrequently ${ }^{19}$. The beneficent side of the chthonic deities could be celebrated with a participatory sacrifice ${ }^{20}$, so that a cultic feast of the living in the company of the hero, was considered quite normal ${ }^{21}$. Cults of especially popular personages usually lacked chthonic features $^{22}$. On the other hand, the primary link, established at the feast, was not with the object of worship who was considered either as a guest or a host of the banquet, and received his portion as a gift, symbolizing the acknowledgment of his power ${ }^{23}$. The meaning of the ritual meal was to establish particular relations, specific intimacy between those who ate the sacrificial meat together ${ }^{24}$,

The combination of sacrificing and banqueting was a normal component of both pious and polite behavior ${ }^{25}$. Thus, the joint feast with the deity retained a direct cultic significance, but to a certain extent it was also a pretext for a pleasurable social gathering. Indeed, the deity received only symbolic portion of the sacrifice, while the worshippers received all the rest ${ }^{26}$. The importance of the banquet is accentuated by the fact that aside from the priest, the host -bestiator- was the main -and often the only one- official of the orgeones.

The details of the orgeones' ceremonies are obscure. The sacrifices were offered by the priest annually, on a fixed date.

17 W. BURKERT, Greek Religion, translated by J. Raffan, Oxford, 1985, p. 199-203. For a summary of the recent research see: S. SCULLION, Olympian and Cbtbonian, in CSCA, 13, 1 (1994), p. 75-119.

18 The word vó $\mu t \mu \alpha$, usually meaning funeral ceremonies, appears only once, in a rather late

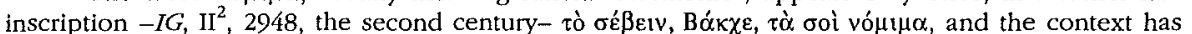

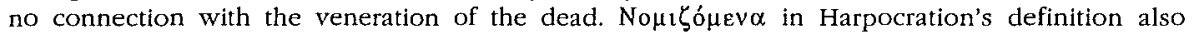
means "rites", and his note about honoring the dead concerns the later period.

19 Scullion, art. cit. (n. 17), p. 97-117. This lack of consistency in the actual ritual gave rise to a tendency to claim that the Olympian/chthonian opposition is essentially a modern construct, see: R. SCHLESIER, Olympian versus Chtbonian Religion, in Scripta Classica Israelica, 11 (1991/92), p. 38-51.

20 SCULLION, art. cit. (n. 17), p. 114.

21 K. MEULI, Griechische Opferbrailche, in Gesammelte Schriften, Basel, 1975, Band 2, p. $916-$ 924; BURKERT, op. cit. (n. 17), p. 205.

22 A.D. NOCK, Cult of Heroes among the Greeks, in HTbR, 37, 2 (1944), p. 144-147; BURKERT, op. cit. (n. 17), p. 208-215.

23 See the detailed argument in: NOCK, art. cit. (n. 22), p. 148.

24 Cf. NOCK, art. cit. (n. 22), p. 149; J.-P. VERNANT, Tbéorie générale du sacrifice, in Le sacrifice dans l'antiquité. Entretiens sur l'antiquité classique, 27 (1981), p. 1-40.

25 J. D. MIKALSON, Athenian Popular Religion, Chapel Hill - London, 1983, p. 89-90.

26 On the Greek sacrificial practice see: BURKERT, op. cit. (n. 17), p. 55-66; L. BRUIT ZAIDMAN, P. SCHMITT PANTEL, La religion grecque, Paris, 1991, p. 20-24. 
It has already been mentioned that the orgeones owned shrines. The decrees of the orgeones of Amynos, Asklepios and Dexion were found in the shrine of Amynos and Asklepios ${ }^{27}$. Several leases of the precincts are preserved: $I G, \mathrm{II}^{2}, 2499$ (late fourth century), IG, $\mathrm{II}^{2}, 2501$ (306/05), SEG, XXIV, 203.

As the lease $I G, \mathrm{II}^{2}, 2499$ indicates that the lessee had to provide two triklina for the annual banquet of the orgeones, it may be supposed that the number of participants in the feast was between twelve and thirty persons ${ }^{28}$. The orgeones of Ekhelos ${ }^{29}$ were much more numerous: they offered a bull as a sacrifice, and as is clear from $I G, \mathrm{II}^{2}, 47$, a bull was sufficient for more than 100 persons. The statute of the orgeones states explicitly that family members also take part in the feast. The list of orgeones who belonged to one of the Attic demes ( $\left.I G, \mathrm{II}^{2}, 2355\right)$ contains 16 names which unquestionably are those of relatives. Evidently, such was the usual composition of the orgeones corporations of the classical type.

The orgeones were reckoned among the demotai, and they possessed land. Thus their citizenship is beyond doubt: non-citizens were not entitled to own land in Attica, and a special permission of the boule and demos was required to purchase land for a sanctuary ( $c f . I G, \mathrm{II}^{2}, 1238 ; I G, \mathrm{II}^{2}, 337$ ).

Some of the orgeones occupied prominent social positions. Among the orgeones of Amynos, Asklepios and Dexion, for example, were several influential persons, who are known from other sources ${ }^{30}$.

Since the orgeones of Amynos, Asklepios and Dexion were wealthy citizens, they could afford to adorn their magistrates with crowns of gold, costing 500 drachmas each. They could also afford $\dot{\alpha} \tau \varepsilon \dot{\lambda} \varepsilon \epsilon \alpha \tau \hat{\imath} \chi 0 \hat{v}$, a privilege which the corporations seldom granted: they were not inclined to reduce their income ${ }^{31}$. The orgeones of Heracles on Lemnos (obviously, Athenian kleroukhoi) granted loans of 1000 and 100 drachmas $(I G$, XII 8, 19; 21) and owned a large sanctuary $\left(15 \times 32 \mathrm{~m}^{2}\right)^{32}$.

Usually, however, the orgeones were much more modest in their expenses. The orgeones of Egretes leased their precinct for 200 drachmas per year, and the orgeones of Hypodektes, for 50 drachmas only. The orgeones of "the Hero" (SEG, XXIV, 203) loan their garden for just 20 drachmas. The sacred law of the orgeones of Ekhelos stipulated in minute detail the relative portions to be received by adult men, by women and by children. They also contain

27 A. KÖRTE, Die Ausgrabungen am Westabbange der Akropolis, in $M D A I(A), 21$ (1896), p. 305; FERGUSON, art. cit. (n. 2), p. 86.

28 One couch accommodated from two to five persons, according to vase paintings, see FERGUSON, ait. cit. (n. 2), p. 81, note 27.

29 MERITT, art. cit. (n. 13), p. 286

30 KÖRTE, art. cit. (n. 27), p. 308.

31 FOUCART, op. cit. (n. 3), p. 39.

32 W. FREDRICH, Lemnos, in $\operatorname{MDAI}(A), 31$ (1906), p. 251. 
provisions for the case, where a bull was unobtainable. Moreover, it is clear, that the matrons were accompanied by housemaids.

This evidence demonstrates that the orgeones "of the classical type" were middle-class citizens ${ }^{33}$.

The corporations of orgeones were based upon democratic laws, which imitated those of the Athenian state ${ }^{34}$. The association decided upon economic questions together, adopted sacred laws ${ }^{35}$, nominated magistrates and awarded honors to its distinguished fellow members. The magistrates were not numerous. There were hosts (hestiatores) and priests in all the associations, and in a number of them, treasurers. The host was the most important person in all the corporations. In many associations not only was he the only magistrate, he had to prepare everything necessary for the sacrifice, and he was also the life and the soul of the banquets. It is obvious why it was to the hosts that most of the honorary decrees were dedicated.

The income of the orgeones included entrance and annual fees, leases, interest on loans, and fines paid by offenders of the laws. Their expenses comprised the maintenance of shrines, the costs of sacrifices, and awards.

\section{The origin of the orgeones}

Certain wo-ro-ki-jo-ne jo c-re-mo (ka-ma) appear in the Pylos tablets ${ }^{36}$, a term of which nothing is known so far. Any connection between it and the Attic orgeones cannot be established at present.

By the time of Solon the orgeones have already existed. When and why did they appear?

The confusion between gennetai, thiasotai and orgeones in a number of lexicographic definitions has already been mentioned. But for every confusion there is a reason. What was it in our case?

The examination of the evidence on this question should begin with a fragment of Philochoros, cited by Photius and Suda (s.v. óprêves, FGH $328 \mathrm{~F}$ 35 a):

About the orgeones Philochoros also wrote, that to phratores orgeones and

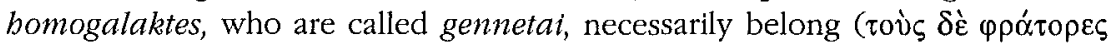

33 See FERGUSON, art. cit. (n. 2), p. 139-140. For the contrary opinion which considers the orgeones poor strangers: ZIEBARTH, op. cit. (n. 3), p. 125; C. HIGNETT, A History of the Atbenian Constitution, Oxford, 1952, p. 47.

34 Like all the other subdivisions of the Athenian demos: R. OSBORNE, The Demos and its Subdivisions in Classical Atbens, in O. MURRAY and S. PRICE (eds.) The Greek Ctty, Oxford 1991, p. $270-275$.

35 Only one sacred law of the fifth century is preserved; there are a number of more recent sacred laws of the orgeones: F. SOKOLOWSKI, Lois sacrées des cttés grecques, Paris, 1962.

36 M. VENTRIS, J. CHADWICK, Documents in Mycenaean Greek, Cambridge, 1956, no. 152.7; 171.11, comm. p. 265, 454. 


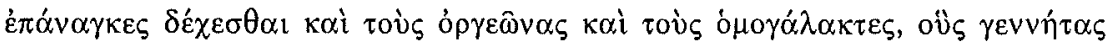
$\kappa \alpha \lambda \mathrm{o} \mu \varepsilon v)$.

This note is important in itself, for it indicates that the orgeones were necessarily citizens. But how were bomogalaktes, gennetai and orgeones interconnected?

Pollux, VIII, 111:

Those belonging to genos are gennetai and bomogalaktes, and they are designated so not because of common origin, but because of an assembly of

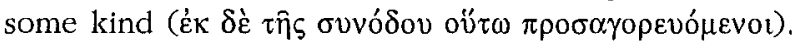

Etym. magn., s.v. $\gamma \varepsilon v v \hat{\tau} \tau \alpha \mathrm{l}:$

Genos is a compact corporation of thirty men, and those belonging to it are called gennetai. They are connected not by origin and not by blood relationships, but exactly as [in the case of] demotai and phratores, they have laws in

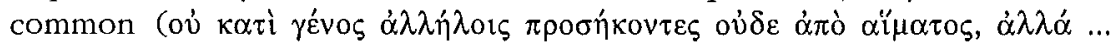

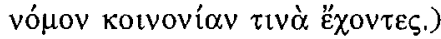

Suda and Harpocration $(s, v, \gamma \varepsilon v \vee \tilde{\eta} \tau \alpha \boldsymbol{t})$ provide essentially the same information.

In the most simple terms, one may say that in the classical period the genos was a clan, consisting of several dozen adult men ${ }^{37}$. It included families, oikoi. The clans formed a distinct social stratum, which however did not coincide entirely with the class of hereditary nobility ${ }^{38}$. The members of each genos-gennetai- performed a joint cult, usually of their alleged mythical ancestor. This cult, which naturally involved sacrifices and meals, was exclusively reserved to the members of the specific clan, thus defining the identity

37 The most detailed treatise on the history and nature of the genos is H. BOURRIOT, Rechercbes sur la nature du génos, T. 1-2. Paris, 1976. See also: D. ROUSSEL, Tribu et cité. Études sur les groupes soclaux dans les cités grecques aux époques archaique et classique, Paris, 1976. A recent attempt to question the effectiveness of gene in Attica (M. STAHL, Aristokraten und Tyrannen im archaiscben Atben, Stuttgart, 1987, p. 79-86) and substitute individual oikoi for gene appears to contradict the extant evidence, which maintains the essential role of the clans.

38 A number of scholars argued that all Athenians were gennetai in the initial state of the development of the polis. H.T. WADE-GERY, Eupatridat, Arcbons and Areopagus, in CQ, 25 (1931), p. 2-3; M.T.W. ARNHEIM, Aristocracy in Greek Society. London, 1977, p. 194; C. ROEBUCK, Three Classes (?) in Early Atbens, in Hesperia, 43 (1974), p. 485-493. However, it seems hard to maintain that numerous immigrants who had joined the civic community by the beginning of the Archaic age, enjoyed the position of gennetal. - The existence of hereditary aristocracy (eupatridai) in Athens also has not remained unchallenged, see T.J. FIGUERA, The Ten Archontes of 579/8 at Atbens, in Hesperia, 53 (1984), p. 452-459. For the opposite view, namely, that gene should be considered to be made up exclusively of the aristocracy see: J. TOPFFER, Attiscbe Genealogie, Berlin, 1889; G. BUSOLT, H. SWOBODA, Griechiscbe Staatskunde, B. 2, München, 1926, p. 772; E. MEYER, Forscbungen zum alte Gescbicbte, B.2., Halle, 1899, p. 517 sq; HIGNETT, op. cit. (n. 33), p. $67 \mathrm{sq}$. 
of each genos as a distinct group ${ }^{39}$. Traditionally it was the reverence of heroes and of minor deities, i.e. the local cults, that belonged to the domain of the gene, which originated in the part of the country with which a given legend was connected. Already by the end of the eighth century the hero cults manifested primarily the group solidarity of the partakers and their connection to the area where the hero was worshipped (and where his grave was usually situated) and its mythical past ${ }^{40}$. Thus, the clan cult was basically an assertion of its unity and attachment to a specific territory, though the deity could have been regarded as the founding hero and be honored as such.

According to the still prevailing view, the kinship subdivisions of the community, such as pbyle, pbratria, genos, dating back to the prehistoric tribal past, have survived into the archaic polis ${ }^{41}$, although the details of this organization have always been debated. D. Roussel and F. Bourriot ${ }^{42}$ have challenged this view, maintaining that formal system of kinship organization evolved only later, in a developed Greek state. This approach has been accepted by a number of scholars ${ }^{43}$. However, it raises more questions than answers, for if there was no tribal order in Greece before the emergence of the state, then to what group larger than family did men owe allegiance ${ }^{44}$ ? It is difficult to believe that the social order was based entirely on the territory and personal relationships ${ }^{45}$. Thus, one cannot think of a better model than a tribal system to explain the existence of some organized social entities, suggested by the archaeological evidence ${ }^{46}$. It seems reasonable that this system was not a continuation of the Mycenaean kingships, but rather a development of the Indo-European tradition ${ }^{47}$ which was shared both by the Achaeans and the later invaders (differences between them probably explaining the divergence

39 Chr. SOURVINOU-INWOOD, What is Polis Religion?, in O. MURRAY and S. PRICE (eds), The Greek City, Oxford, 1991, p. 312.

40 BURKERT, op. cit. (n. 17), p. 204 ; SOURVINOU-INWOOD, art. cit. (n. 39), p. 270-275. - At the moment it is insubstantial for us, whether the eighth-century hero cults were a continuation of the Mycenaean cults, as argues M.P. NILSSON (The Minoan-Mycenaean Religion and its Survival in Greek Religion, Lund, 1950 , p. 584-615), or derive from the influence of the epic poetry, according to W. BURKERT (loc. cit.).

41 To cite only a few examples: J. DAY, M. CHAMBERS, Aristotle' History of Atbenian Democracy, Amsterdam, 1967, p. 161; HIGNETT, op. cit. (n. 33), p. 57-59; O. MURRAY, Early Greece, London, 1993; H. JEANMAIRE, Courol et Courètes, Lille, 1939, p. 97-11; J.N. GOLDSTREAM, Geometric Greece, London, 1977, p. 314.

42 op. cit. (n. 37).

43 W. DONLAN, The Social Groups of Dark Age Greece, in CPb, 80 (1985), p. 305-308.

44 A. SNODGRASS, Archaic Greece, Berkeley-Los Angeles, 1980, p. 26.

45 As W. DONLAN suggests, art. ctt. (n. 43), p. 298-305.

46 SNODGRASS, op. cit. (n. 44), p. 26.

47 P. LÉVÊQUE, La genèse de la cité grecque, in La pensée, 217 (1981), p. 26. 
between the Ionian ${ }^{48}$ and Dorian tribal systems). Thus, pbyle and genos must have existed all through the Dark Ages, although pbratry presumably emerged at a later stage, but not later than the eighth century ${ }^{49}$. In any case, nearly nobody doubts the fact that by the beginning of the eighth century phyle, gene and phratries had already come into being ${ }^{50}$.

The Attic tradition, which is certainly vague when dealing with the remote past, relates two instances of the incorporation of considerable groups of strangers into the civic community: Thuc., I, 2, 6 and Plut., Thes., 25. This practice may have been established in the late Mycenaean period, when Athens remained the only stronghold not to have suffered from the collapse ${ }^{51}$. These foreigners, that fled from the disorder in their home countries (Thuc., I, $2,6)$, were probably oi $\delta v v \alpha \tau \omega ́ \tau \alpha \tau o r$, nobles accompanied by betairoi, rhapsodes, artisans, etc. Apparently, it was with the prospect of acquiring citizenship that people immigrated to Attica even after the synoikism (Plut., Thes., 25).

In addition to the ancient tradition, the archaeological evidence also testifies to a considerable influx of foreign population to Attica during the Dark Ages $^{52}$.

These immigrants joined the civic community. However, the "autochthonous" Athenians could not fail to differentiate these newcomers from themselves, though perhaps in this respect a distinction was made between noble immigrants and their retinue.

The term bomogalaktes was a puzzle to the lexicographers as well. A key to its solution may be found ${ }^{53}$ in Aristotle's note (Pol., 1252 b 18) indicating that a family or a rural community may include a number of members that are not connected to the rest by kinship, and the members of these communities

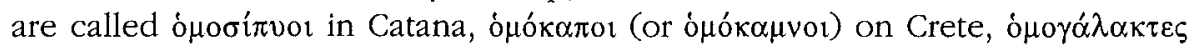
in Athens.

Evidently, new members of a family or of a rural community were incorporated through the ceremony of a joint ritual meal. It is quite reasonable to suppose that the clans admitted new members in the same way. Having acquired the status of bomogalaktes, the newcomers received the full rights of

48 On the Ionian tribes see M. PIÉRART, Modèles de répartition des citoyens dans les cités ioniennes, in RAC, 87 (1985), esp. p. 185-186 on their pre-Homeric origin.

49 COLDSTREAM, op. cit. (n. 41), p. 314; A. ANDREWES, Pbratries in Homer, in Hermes, 89 (1961), p. 129-140.

50 R. SEALEY, How Citizenship and the City began in Atbens, in AJAH, 8, 2 (1983), p. 115; DONLAN, art. cit. (n. 43), p. 297, note 14; p. 307.

51 N.G.L. HAMMOND, Land Tenure in Attica and Solonis Setsacbtbeia, in JHS, 81 (1961), p. 78 81; G. E. MYLONAS, Mycenae and the Mycenaean Age, Princeton-New Jersey, 1966.

52 V. R. D'A. DESBOROugh, The Greek Dark Ages, London, 1972, p. 341.

53 N.G.L. HAMMOND was the first to pay attention to this phrase in this context: art. cit. (n. 51), p. 81 . 
the gennetai, and hence after several generations they were practically indistinguishable from the community of indigenous Athenians (cf. Harpocr., Suda, s.v. $\gamma \varepsilon v \vee \eta \hat{\tau} \alpha \imath)^{54}$.

But, as Thucydides says (I, 2, 6), the flow of refugees swelled even later. In the early Archaic period, on the background of the astonishing population growth ${ }^{55}$, the rapid social, economic and political developments have conditioned an increasing population mobility ${ }^{56}$, and consequently the crystallizing polis continued to absorb immigrants. Solon's immigration law, mentioned by Plutarch (Solon, 24, 4), clearly testifies, that in the pre-Solonic Attica there were several categories of immigrants, seeking the Athenian citizenship, and the legislator bestowed the citizen rights on two groups, those in permanent exile from their native land, and craftsmen ${ }^{57}$.

At a certain moment -which cannot be dated precisely- it was no longer possible to grant all immigrants the same rights as the old members of the civic community. It seems quite probable that gradually some restriction began to be imposed on the rights of the immigrants: they continued to receive citizenship, were accepted into phratries ${ }^{58}$, but not into gene.

The evidence on the social and political structure of Attica towards the end of the Dark Ages is so vague that any reconstruction is problematic. But one cannot dismiss altogether the entire ancient tradition on the early history of Attica as legendary and unreliable, especially since it is being constantly supported by the newly acquired archaeological data ${ }^{59}$. It should be accepted in most general terms, that by the beginning of the eighth century the population of

54 F. JACOBY (FGH, III. 1, p. 221) considered bomogalaktes and gennetai to be synonyms. M. MILLER (Greek Kinship Terminology, in JHS, 73 [1953], p. 43-52) suggested, that bomogalaktes are people of common origin. R. J. LITTMAN (Kinship in Atbens, in Ancient Societ), 10 [1979], p. 23) thought that bomogalaktes were included in phratries on their mothers' side.

55 According to the calculations of A. SNODGRASS (op. cit. [n. 44], p. 23) between about 780 and 720 , the population multiplied itself by a factor of approximately seven. The hypothesis of population boom has been recently reassessed, see N. PURCELL, Mobility and the Polis, in O. MURRAY and S. PRICE (eds), The Greek City, Oxford, 1991, p. 45. But even if absolute figures are unobtainable, there is no doubt about the extremely rapid population growth which cannot be explained by mere increase in birthrate (MURRAY, op. cit. [n. 41], p. 64).

56 PURCELL, art. cit. (n. 55), p. 48-57.

57 For a commentary see : J. K. DAVIES, Athenian Citizenship: the Descent Group and The Alternatives, in GJ(1977/78), p. 105-121; SEALEY, art. cit. (n. 50), p. 111-115. R. Sealey justly notes, that "approached from the standpoint of classical Athens, the law is surprising, because it offers citizenship to people who would later have become metics. The law is less surprising, if approached in the light of earlier conditions, attested in the Homeric poems and elsewhere" (p. 112). However, the general idea of R. Sealey's paper, that citizenship as a formal category emerged in Athens only after Solon, and that it was only after the reforms of Cleisthenes that the distinction between citizens and aliens crystallized, seems unacceptable.

58 That every citizen was a member of a phratry follows indisputably from Draco's law (IG, $\mathrm{II}^{2}$, 115; cf. HIGNETT, op. cit. [n. 33], p. 55, 67).

59 See GOLDSTREAM, op. cit. (n. 41); v. R. D'A. DESBOROUGH, op. cit. (n. 52); SNODGRASS, op. cit. (n. 44). 
Attica included not only autochthonous Athenians, but immigrants and their descendants, too. These people could have become orgeones.

In what form were the immigrants admitted to the cults?

As certain cults could be performed only by specific clans, non-gennetai found themselves outside the cults of the gene. Thus although the immigrants even were accepted into phratries they lacked the right to participate in the ceremonies of the clans.

In order to understand the implications of this exclusion it is necessary to stress some aspects of the Greek religion.

First, Greek popular religion was a religion of ritual action, and not of a prayer or conviction ${ }^{60}$. The Greeks believed in the direct connection between performing specific ritual and obtaining the favorable disposition of the deity. If unable to perform the necessary rites, a Greek would have felt deprived of the protection of the gods, and in the case of a new immigrant to Attica, would have lacked the patronage of the local deities, mostly heroes, those being most effective in the particular place where he lived ${ }^{61}$.

Second, a sacrifice was followed by a feast. Given the fish and vegetable diet to which the Greeks were limited, the aroma of roasted meat cooked by neighbors must have been very tempting.

The third and even more important factor was the desire for personal contacts and membership in associations, the enjoyment of which was one of the basic components of the Greek way of life. The abundance of corporations which were structural components of the state, such as demes, clans, phratries, and private associations, stretching from organizations of traders ${ }^{62}$ to betaireiai ${ }^{63}$, established a special corporate atmosphere in the polis. As R. Osborne aptly puts it, "the citizen body was united by its divisions" 64 . Moreover, even the state itself was conceived as a corporation of its citizens (Aristt., Eth. Nic., 1160 a 28). All these various polis subdivision were articulated

60 M.P. NILSSON, Greek Popular Religion, New York, 1940, p. 76; BRUIT ZAIDMAN, SCHMITT PANTEL, op. cit. (n. 26), p. 19.

61 Gf. BURKERT, op. cit. (n. 17), p. 205.

62 A number of them are mentioned in the law, ascribed to Solon, which is preserved in the

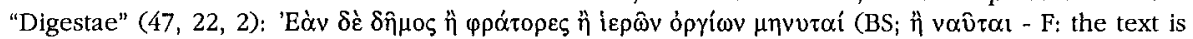

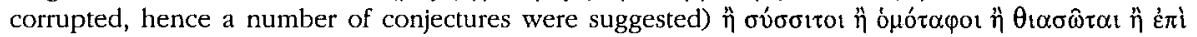

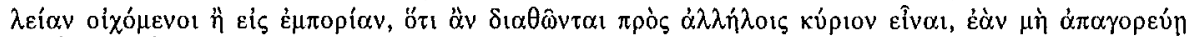
$\delta \eta \mu o ́ \sigma ı \alpha ~ \gamma \rho \alpha ́ \alpha \mu \alpha \tau \alpha$. - See commentaries in: G. BUSOLT, Griechische Gescbicbte, B. 2, Gotha, 1895, p. 117; U. VON WILAMOWITZ-MÖlLENDORFf, Antigonos von Karystos, Berlin, p. 278; FERGUSON, art. cit. (n. 2), p. 64, n. 5; HAMMOND, art. ctt. (n. 51), p. 80, n. 2; M. GUARDUCCI, Orgeoni i tiasoti, in RFIS n.s., 13 (1935), p. 338; M. RADIN, op. cit. (n. 15), p. 48-49. - Leaving aside the paleographical discussion and the problem of whether this particular law belonged to the codex of 594 or 409-401, we may state that at least in the last decade of the fifth century all the corporations in Athens were declared lawful, if they did not violate the laws of the state, which in turn did not interfere in their internal affairs.

63 See a most comprehensive work: G.M. CALHOUN, Atbenian Clubs in Politics and Litigation, in Bull. of the Univ. of Texas, No 262. Humanistic Series No 14. 1913.

64

Art. cit. (n. 34), p. 267; cf. also 275. 
and given identity through cult ${ }^{65}$, and all of them adopted a single norm of organization and standard of action, thus reinforcing the ideological uniformity of the citizen body ${ }^{66}$. This corporate atmosphere determined the character of the individual's reactions in certain situations, and conditioned his social behavior.

Thus, although the newcomers were admitted into phratries, they wished to belong to more intimate groups, as well. The immigrants saw the clans as a model which could satisfy their need to belong to a small circle of congenial persons.

The functions of gene were mainly cultic, and this was of extreme importance. The gennetai were aware that their kinship through a common ancestor was fictional. But the joint cult and the sacred meal cemented real attachments between the gennetai, and imposed bonds upon them, for which the nongennetai yearned. That is why, scarcely having settled in the new place, the newcomers, when they could afford to do so, founded corporations "for reverence of heroes and gods" -what other clubs could they establish ? - and usually "the heroes and gods" were precisely of the neighborhood, where the recent immigrants had started their new life.

N.G.L. Hammond held that by the seventh century all Athenians were either gennetai, or orgeones ${ }^{67}$. But the preserved tradition contains no indication that the phratry was divided into gennetai and orgeones ${ }^{68}$. There is no doubt that there was a considerable sub-stratum of pbrateres, who did not belong to either of these organizations.

Hence, the Philochoros' text may be understood as follows: the phratry automatically includes anyone able to prove his belonging to orgeones and bomogalaktes, or in the other words, since bomogalaktes are practically indistinguishable from gennetai, to orgeones or gennetai. In other cases membership is to be treated according to the usual procedures. It is implied that the elite groups of orgeones and gennetai carry out the dokimasia even more strictly than the phratries.

Belonging to the orgeones was important in litigation. For example, in one of Isaeus' orations the speaker, willing to persuade the jury that he was an adopted son of a person whose inheritance he sought, said: "He introduced me to the phrateres present here and enrolled me into demotai and orgeones ( $\mathrm{ki}$

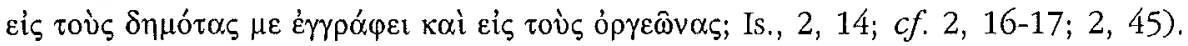
This implies that the orgeones may have had membership lists.

5 SOURVINOU-INWOOD, att. cit. (n. 39), p. 311-312.

66 OSBORNE, art .cit. (n. 34), p. 285.

67 HAMMOND, op. cit. (n. 51), p. 81.

68 Though a given clan must have belonged to a particular phratry, with the aristocratic gene occupying the leading positions in it. 
It is impossible to say precisely whether the orgeones joined the phratry individually ${ }^{69}$, or en bloc $c^{70}$. First of all, phratries may have differed in their structure $^{71}$. An indirect hint to the fact that the associations of orgeones were separated bodies within the phratries, is the poletai inscription of $367 / 66^{72}$. The list of creditors includes koinon orgeonon, who must have belonged to the phratry, otherwise it would be unclear which orgeones were referred to ${ }^{73}$.

We have yet to address the question of the date of the Philochoros' fragment. It was incorporated into book IV of the "History of Attica" (FGH 328 F 35 b), which deals with the period 464-395/4. However, most scholars consider it a digression, ${ }^{74}$ referring either to Solon's time ${ }^{75}$, or to that of Cleisthenes $^{76}$.

When resolving this question, one should take into consideration that even in Draco's time phratries consisted of people of different social standing, which could obviate the need to issue such a law. Solon may have wished to stress this element of tradition; it would be in perfect accordance with his program of establishing social peace and supporting the middle class, which gave rise to orgeones. The preserved tradition is unanimous in agreeing that Cleisthenes did not deal with phratries. But even if he had dealt with them, he would have declared automatic admittance to the phratries for broader masses. Scholars who claim that the law cited by Philochoros was a part of the democratic program ignore the fact that the orgeones, even if common people, were never without kin, or poor.

Thus, it is reasonable to consider the Philochoros' fragment not as a new law, but as a reaffirmation of the existing situation, and to date it back to Solon's legislation.

We may summarize our hypothesis as follows: the corporations of orgeones appeared in Attica after the mass migrations into the country, not later

69 FERGUSON, art. cit. (n. 2), p. 70.

70 RADIN, op. cit. (n. 15), p. 40.

71 For a recent summary of existing opinions see: M.A. FLOWER, IG $I t^{2} 2344$ and the Size of Pbratries in Classical Athens, in CQ, 35 (1985), p. 232-235.

72 M. Crosby, Greek Inscriptions. A Poletai record of the Year 367/6 B.C., in Hesperia, 10, 1 (1941), p. 14-27.

73 M. GUARDUCCI (art. cit. [n. 62], p. 339) suggested, that the phratry was composed of gennetai

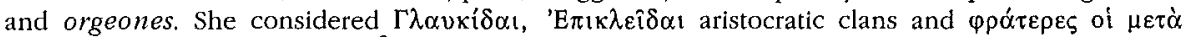
Níkwvos, $\kappa \tau \lambda$. orgeones in $I G, \mathrm{II}^{2}, 2723$. But the associations of orgeones were always titled after the deity.

74 Only A. ANDREWES supposed that it belonged to the main narration of book IV, where Pericles' legislation on phratries is described, and not that of 451 (ARISTT., Ath. Pol., 26, 3), but of the thirties (Pbilochoros on Pbratries, in JHS, 81 [1961], p. 13).

75 U. VON KAHRSTEDT, Staatsgebiet und Staatsangehorige in Athen, Stuttgart-Berlin, 1934, p. 236; FERGUSON, art. cit. (n. 2), p. 69; M.P. NILSSON, Geschichte der griechiscben Religion, B. 1, München, 1955, p. 710.

76 BUSOLT, SWOBODA, op. cit. (n. 38), B. 1, p. 232; B. 2, p. 880, 935; HIGNETT, op. cit. (n. 33), p. 391-392. 
than during the eighth - seventh centuries. The immigrants were enrolled into phratries and received civic rights, but they were not incorporated into clans, hence, along with other privileges, they were unable to partake in the cults of the gene. Equally, their social milieu was limited. For these reasons, in conformity with the general corporate orientation of life in the polis, and following the pattern of the clans, the newcomers established small hereditary groups worshipping local deities. Not all non-gennetai did so. This new form of social organization, corporations of orgeones, became so deeply rooted that it was officially recognized by Solon, and belonging to orgeones began to simplify considerably, if not to abolish, the procedure of dokimasia at the induction of children into the phratry.

\section{Conclusions}

This article is an attempt to demonstrate how the feeling of social and cultic deprivation shared by certain segments of Athenian society during the pre-archaic and archaic periods, resulted in the appearance of private cult associations. The polis itself was conceived as a koinonia, a corporation of citizens, sub-divided into smaller corporations. In an age in which the religion was expressed in actions rather than in words, and in collective rather than individual actions, given the existing example of clans which granted their members security and mutual aid, satisfying religious needs and providing the pleasures of joint banquets, the new citizens did not seek other stimuli and standards, but established their own corporations according to the model of the gene. Although it was only later that membership in these groups began to bestow real social privileges, from the outset the newly founded corporations were already effective in liberating the immigrants from the sense of inferiority and defenselessness, both in the cultic and the social spheres.

The Attic cult associations of the classical period penetrated harmoniously the way of life of the polis, rendering the life of polites more integrated from the point of view of the polis values. The worshipped deities were ancient Attic personages, and the ritual extremely simple. Thus when in the polis, itself a corporation of citizens, other corporations appeared, having the same purposes and features as those of the clans, this innovation not only did not undermine the foundations of the polis, but on the contrary, fortified them. The new corporations established uniformity in the structural units of the polis ${ }^{77}$ and eliminated the motivation for part of the society to feel that their rights were infringed, and to envy the privileges of the elite. Thus the cult associations, which first appeared as private, and afterwards were recognized as civic structures, were important in the implementation of the most important

77 Cf. OSBORNE, art. cit. (n. 34), p. 268, 275. 
principle of existence of a Greek state, the principle of civic consent, bomonoia.

Department of History

Yulia Ustinova

Ben-Gurion University of the Negev

P.O.B. 653

BEER-SHEVA 84105

Istael 